\title{
Preparation Technologies of Straw Char and Its Effect on Pollutants Emission Reduction in Iron Ore Sintering
}

\author{
Xiaohui FAN, Zhiyun JI,* Min GAN, Xuling CHEN, Liang YIN and Tao JIANG \\ School of Minerals Processing \& Bioengineering, Central South University, Changsha, Hunan, 410083 P. R. China. \\ (Received on April 3, 2014; accepted on August 11, 2014)
}

\begin{abstract}
Influences of preparation technologies on properties of straw char (corn) and its use as a supplementary fuel for coke breeze in iron ore sintering were investigated. By means of one-stage carbonisation, produced straw char achieved similar volatile and fixed carbon contents to coke breeze, where recommended carbonisation temperature was $700^{\circ} \mathrm{C}$, heating rate was $10-25^{\circ} \mathrm{C} / \mathrm{min}$, and carbonisation time was $30 \mathrm{~min}$. Two-stage carbonisation, consisting of one low temperature stage and the other high temperature stage, facilitated the further removal of volatile matters, and making straw char increased in yield and fixed carbon content. Recommended one-stage carbonisation benefited reducing combustibility difference between straw char and coke breeze since densified strucuture was achieved. Compared with one-stage carbonisation, two-stage carbonisation made straw char more densified in structure and less difference in combustibility to coke breeze. For straw char prepared from one-stage and two-stage carbonisation, recommended replacement ratio to coke breeze were $20 \%$ and $40 \%$ respectively. The emission reduction of SOx for replacement ratio $20 \%$ and $40 \%$ were $10.98 \%$ and $38.15 \%$ respectively, and that of NOx were $12.67 \%$ and $22.53 \%$ respectively.
\end{abstract}

KEY WORDS: agglomeration; iron ore sintering; bio-energy; straw char; carbonisation; pollutants emission reduction.

\section{Introduction}

As the chief iron-bearing burden of blast furnace for ironmaking in China, sinter makes up a ratio exceeding $75 \%$. $^{1)}$ Sintering process is also energy-intensive that consumes $9-$ $12 \%$ of the total energy in integrated steelworks. $75-80 \%$ of the energy consumed is solid fuels, including coke breeze, anthracite ect. ${ }^{2)}$ Greenhouse gas $\mathrm{CO}_{2}$, polluting gases SOx, NOx etc. have been proved to mainly come from the combustion of fossil fuels during sintering process. ${ }^{3)}$ Therefore, substituting fossil fuels with clean and renewable bio-energy in sinter making contributes to clean sinter production. CSIRO exhibited a great interest in employing charcoal into sintering field, ${ }^{4-6)}$ while Corus mainly put its focus on researching olive residues, sunflower husk pellets ect. ${ }^{7,8)}$ Both of them indicated that biomass fuels replacing fossil fuels benefited emissions reduction of $\mathrm{COx}, \mathrm{SOx}, \mathrm{NOx}$ etc. However, their findings also indicated that biomass fuels combusted faster than coke, which degraded sinter quality mainly for accelerated sintering speed. Uncarbonised raw biomass fuels like sunflower husk pellets had a lower level of fuel utilisation since volatile matters were not used before combustion front approached. For introducing biomass fuels into sinter making in China, our group has investigated the properties and sintering behaviours of charcoal, charred straw and molded sawdust. Emissions of COx, SOx, NOx

* Corresponding author: E-mail: zhiyunji@sina.com DOI: http://dx.doi.org/10.2355/isijinternational.54.2697 etc. have been reduced, while sinter quality decreased markedly when excessive coke breeze was replaced. ${ }^{9,10}$ )

Therefore, it is necessary to prepare desirable biomass fuels for iron ore sintering process. However, no research about the preparation technologies of biomass fuels for iron ore sintering purpose is found. Fuels needed for sinter making are supposed to be lower in volatile matters and to have proper combustion rate. ${ }^{11)}$ Coke breeze has been proved to be a typical kind of fuels that well match heating transfer speed for sinter making. ${ }^{11)}$ This investigation focused on searching proper preparation technologies for producing expected biomass fuels. $17 \%$ of the world total straw resources is distributed in China, ${ }^{12)}$ while its availability is less than $45 \%$ for open burning and being abandoned. ${ }^{13,14)}$ For environmental and economic purposes, raw straw therefore was applied to prepare desired supplemental fuel-straw char for coke breeze by means of carbonisation processing. A laboratory-scale sinter pot was used to evaluate its applying effect during sinter making.

\section{Materials and Methods}

\subsection{Properties of Materials}

For making sinter, iron ores, fluxes (dolomite, limestone and quick-lime), fuels and return fines were all provided by an integrated steelwork in China. According to ore blending scheme adopted in the sinter plant, mass contents of $\mathrm{Fe}$, $\mathrm{SiO}_{2}$, and $\mathrm{MgO}$ in sinter were kept at $56.38 \%, 4.92 \%$, and $2.0 \%$ respectively. Basicity $\left(\mathrm{CaO} / \mathrm{SiO}_{2}\right.$, mass $\left.\%\right)$, which was 
adjusted through changing flux levels, in sinter was kept at 1.9. The chemical composition and proportions of raw materials are given in Table 1. Since the influence of different fuels on chemical composition of mixtures mainly depended on their ash composition, this influence was neglected in our investigation for lower fuel ratio in mixture and lower ash ratio in fuel.

Coke breeze and raw corn straw were employed in this investigation. Raw corn straw used to prepare straw char had been briquetted into pellets of $10 \mathrm{~mm}$ diameter $\times 20 \mathrm{~mm}$ long by a briquetter working at a maximum pressure of 180 $\mathrm{MPa}$ and maintained for 1 min without any binder at room temperature. The density of raw straw was then increased from $0.25 \mathrm{~kg} / \mathrm{m}^{3}$ to $1.22 \mathrm{~kg} / \mathrm{m}^{3}$. Coke breeze was a typical kind of sinter fuels, which had a size range of mainly 0.5 mm-3 mm. By means of Automatic Proximate Analyser, model SDTGA5000 (Sundy, China) and CHNOS Elemental Analyser, model Vario EL III (ELEMENTAR, Germany), proximate and ultimate analyses of raw straw and coke breeze illustrated in Table 2 showed that raw straw mainly consisted of volatile matters, which accounted for $82.37 \%$, and its calorific value was lower than coke breeze. Since coke breeze came from coking plant, its major part was fixed carbon.

Table 1. Chemical composition and proportion of individual raw material in mixture.

\begin{tabular}{|c|c|c|c|c|c|c|c|c|}
\hline \multirow{2}{*}{$\begin{array}{l}\text { Sorts of raw } \\
\text { materials }\end{array}$} & \multicolumn{7}{|c|}{ Chemical composition } & \multirow{2}{*}{ Proportion } \\
\hline & $\mathrm{TFe}$ & $\mathrm{SiO}_{2}$ & $\mathrm{CaO}$ & $\mathrm{MgO}$ & $\mathrm{Al}_{2} \mathrm{O}_{3}$ & $\mathrm{FeO}$ & $\mathrm{LOI}^{\mathrm{a}}$ & \\
\hline Mixed iron ores & 60.74 & 4.65 & 1.9 & 1.54 & 1.92 & 9.24 & 2.64 & 64.93 \\
\hline Dolomite & 0.21 & 0.87 & 31.57 & 19.68 & 0.22 & 0.13 & 46.91 & 0.53 \\
\hline Limestone & 0.14 & 1.31 & 50.19 & 3.30 & 0.32 & 0.10 & 42.27 & 3.05 \\
\hline Quick-lime & 0.40 & 2.85 & 77.92 & 3.64 & 0.75 & 0.23 & 11.29 & 4.56 \\
\hline Return fines & 56.38 & 4.92 & 9.36 & 2.00 & 2.07 & 8.58 & 0.00 & $23.08^{\mathrm{b}}$ \\
\hline Fuel & - & - & - & - & - & - & - & 3.85 \\
\hline
\end{tabular}

\subsection{Experimental Methods}

2.2.1. Straw Char Preparation and Properties Examination

Corn straw char was prepared in an electrically heated shaft furnace, depicted in Fig. 1. For each run, $200 \mathrm{~g}$ straw pellets were initially loaded into a quartz tube, and then moved the tube into the furnace. Two types of carbonisation processes, one-stage carbonisation and two-stage carbonisation, were employed to prepare straw char. During one-stage carbonisation, variable factors like heating rate, carbonisation temperature, carbonisation time, and reaction atmosphere, and their levels were given in Table 3. When determining the influences of one factor, other factors were remained constant. Two-stage carbonisation described in more detail

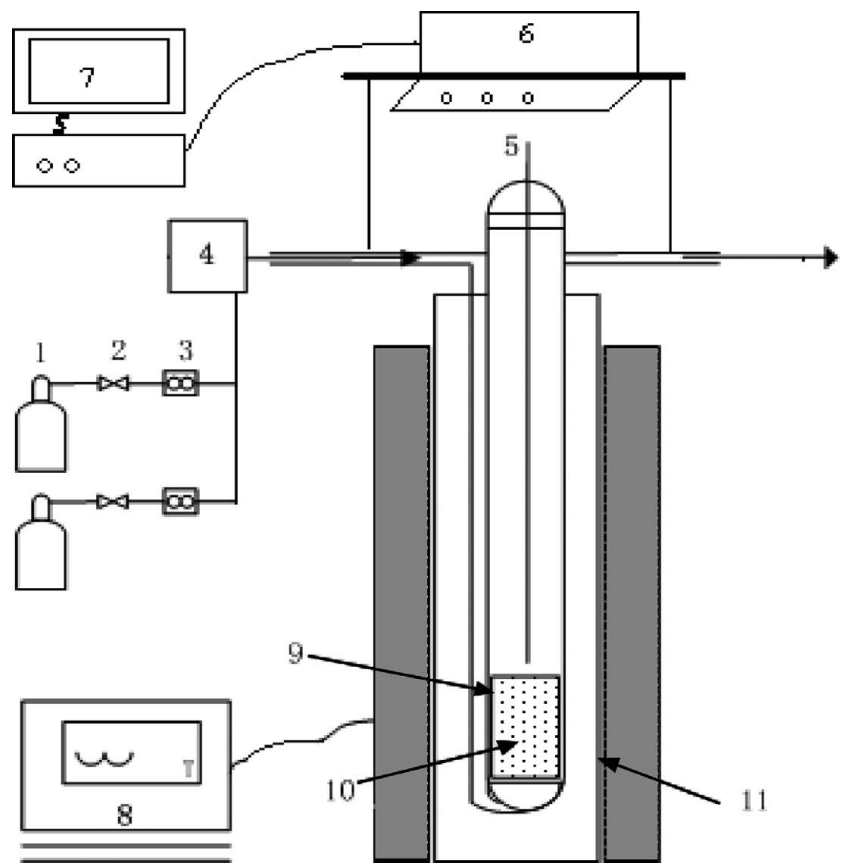

Fig. 1. Schematic diagram of carbonisation equipment. 1-gas bottles; 2-reducing valve; 3-flowmetre; 4-gas mixing bottle; 5-thermocouple; 6-electronic balance; 7-computer; 8-temperature regulator; 9-quartz reactor; 10-raw material cup; 11-shaft heating furnace.

Table 2. Proximate and ultimate analyses of fuels (dry basis).

\begin{tabular}{|c|c|c|c|c|c|c|c|c|c|}
\hline \multirow{2}{*}{ Fuel types } & \multicolumn{5}{|c|}{ Ultimate analyses (mass\%) } & \multicolumn{3}{|c|}{ Proximate analyses (mass\%) } & \multirow{2}{*}{ Calorific value $(\mathrm{MJ} / \mathrm{kg})$} \\
\hline & $\mathrm{C}$ & $\mathrm{H}$ & $\mathrm{O}$ & $\mathrm{N}$ & $\mathrm{S}$ & Ash & Volatile & Fixed carbon & \\
\hline Raw straw & 44.69 & 5.10 & 45.49 & 0.27 & 0.089 & 4.36 & 82.37 & 13.27 & 18.80 \\
\hline Coke breeze & 76.33 & 2.29 & 0.96 & 0.67 & 0.209 & 19.54 & 4.88 & 75.68 & 28.06 \\
\hline
\end{tabular}

Table 3. Factors and their levels for one-stage and two-stage carbonisation.

\begin{tabular}{|c|c|c|c|c|c|}
\hline Carbonisation processes & Factors & \multicolumn{4}{|c|}{ Levels } \\
\hline \multirow{4}{*}{ One-stage } & Carbonisation temperature $\left({ }^{\circ} \mathrm{C}\right)$ & 500 & 600 & 700 & 800 \\
\hline & Heating rate $\left({ }^{\circ} \mathrm{C} / \mathrm{min}\right)$ & 10 & 25 & 100 & 200 \\
\hline & Carbonisation time (min) & 10 & 20 & 30 & 60 \\
\hline & Reaction atmosphere & \multicolumn{4}{|c|}{$\mathrm{N}_{2}$ with flow rate $0.1 \mathrm{~L} / \mathrm{min}$} \\
\hline \multirow{3}{*}{ Two-stage } & Carbonisation temperature of stage- $1\left({ }^{\circ} \mathrm{C}\right)$ & 400 & 500 & 600 & \\
\hline & Carbonisation temperature of stage- $2\left({ }^{\circ} \mathrm{C}\right)$ & 700 & & & \\
\hline & Reaction atmosphere & \multicolumn{4}{|c|}{$\mathrm{N}_{2}$ with flow rate $0.1 \mathrm{~L} / \mathrm{min}$} \\
\hline
\end{tabular}


elsewhere ${ }^{16)}$ consisted of two sequential one-stage carbonisation processes. However, in this investigation, carbonisation process was directly moved from lower temperature stage1 to the higher temperature stage- 2 without any cooling between these two stages. Factors and their levels for twostage carbonisation are also given in Table 3. Heating rate and carbonisation time for stage- 1 and stage- 2 were the same, which were determined by the selected values in onestage carbonisation.

After carbonisation, straw char was cooled to room temperature in $\mathrm{N}_{2}$ with a flow rate of $0.1 \mathrm{~L} / \mathrm{min}$, and its weight was measured. Equation (1) was used to calculate the yield of straw char, which was an important factor to assess carbonisation effect. Optical microscope, model DMRXP (Leica, Germany) and CHNOS Elemental Analyser were employed to examine microstructure and chemical composition of straw char.

$$
W=\frac{M_{1}}{M_{2}} \cdot 100 \%
$$

Where $W$ is the yield (\%), $M_{l}$ is the mass of final solid product $(\mathrm{g}), M_{2}$ is the mass of dried straw charged for carbonisation $(\mathrm{g})$.

According to analysed yield and $\mathrm{C}, \mathrm{H}$, and $\mathrm{O}$ levels of straw char, Eq. (2) was used to calculated the removal ratio of $\mathrm{C}, \mathrm{H}$ and $\mathrm{O}$ during carbonisation, where $P$ is the removal ratio of $\mathrm{C}(\mathrm{H}$, or $\mathrm{O}), w_{1}$ is the level of $\mathrm{C}(\mathrm{H}$, or $\mathrm{O})$ in raw straw, $w_{2}$ is the level of $\mathrm{C}(\mathrm{H}$, or $\mathrm{O})$ in straw char, $W$ is the yield.

$$
P=\frac{w_{1}-W w_{2}}{w_{1}} \cdot 100 \%
$$

Isothermal weight loss rate was measured with the same equipment shown in Fig. 1 to describe the combustibility of straw char. $25 \mathrm{~g}$ straw char with size range of 3-5 mm was loaded into a quartz tube, and only $\mathrm{N}_{2}$ with a flow rate of 5 $\mathrm{L} / \mathrm{min}$ was supplied. The combustion reaction started at $900^{\circ} \mathrm{C}$ in simulated air atmosphere, of which flow rate was $5 \mathrm{~L} / \mathrm{min}$. During the whole combustion process, weight change of straw char was collected by a computer. According to the data recorded, fuel conversion rate $x_{c}$ used to evaluate fuel burning speed was calculated by Eq. (3).

$$
x_{c}=\frac{m_{0}-m}{m_{0}} \cdot 100
$$

Where $x_{c}$ is fuel conversion rate $(\%), m_{0}$ is initial mass $(\mathrm{g}), m$ is the mass at time $t(\mathrm{~g})$.

\subsubsection{Description of Sintering Trials}

Sintering trials were conducted in a $700 \mathrm{~mm}$ deep $\times 180$ $\mathrm{mm}$ diameter sinter pot, and its schematic diagram was given in Fig. 2. Raw materials introduced ahead were blended manually together according to their proportions, during which water was added to achieve prescribed moisture content. After that, mixed materials were charged into an electrically powered drum for granulation. The drum was 1400 $\mathrm{mm}$ deep $\times 600 \mathrm{~mm}$ diameter, and granulation was conducted at $15 \mathrm{r} / \mathrm{min}$ for $4 \mathrm{~min}$. Before charging granulated mixtures, $1 \mathrm{~kg}$ sinter of size range $10 \mathrm{~mm}-16 \mathrm{~mm}$ was charged as hearth layer. An ignition hood was employed to ignite the fuel in the surface layer with natural gas fuelled and a set of downdraught system was used to sustain combustion front to move downwards. Ignition period involved $1 \mathrm{~min}$ at $1050^{\circ} \mathrm{C} \pm 50^{\circ} \mathrm{C}$ and a pressure drop of $5 \mathrm{kPa}$. The pressure drop was changed to $10 \mathrm{kPa}$ for sintering, and then to $5 \mathrm{kPa}$ for cooling. The total sintering time was measured from the start of ignition to the point where the sinter waste gas had reached a maximum temperature. During the whole sintering process, infra-red flue gas analysers, model DELTA 653 and Vario Plus (MRU Corporation, Germany), were adopted to measure the concentration of $\mathrm{O}_{2}, \mathrm{CO}, \mathrm{CO}_{2}, \mathrm{NOx}$, and $\mathrm{SO}_{2}$ in flue gas.

During sinter quality tests, RFB (return fines balance) was regarded as an important index to validate the test of

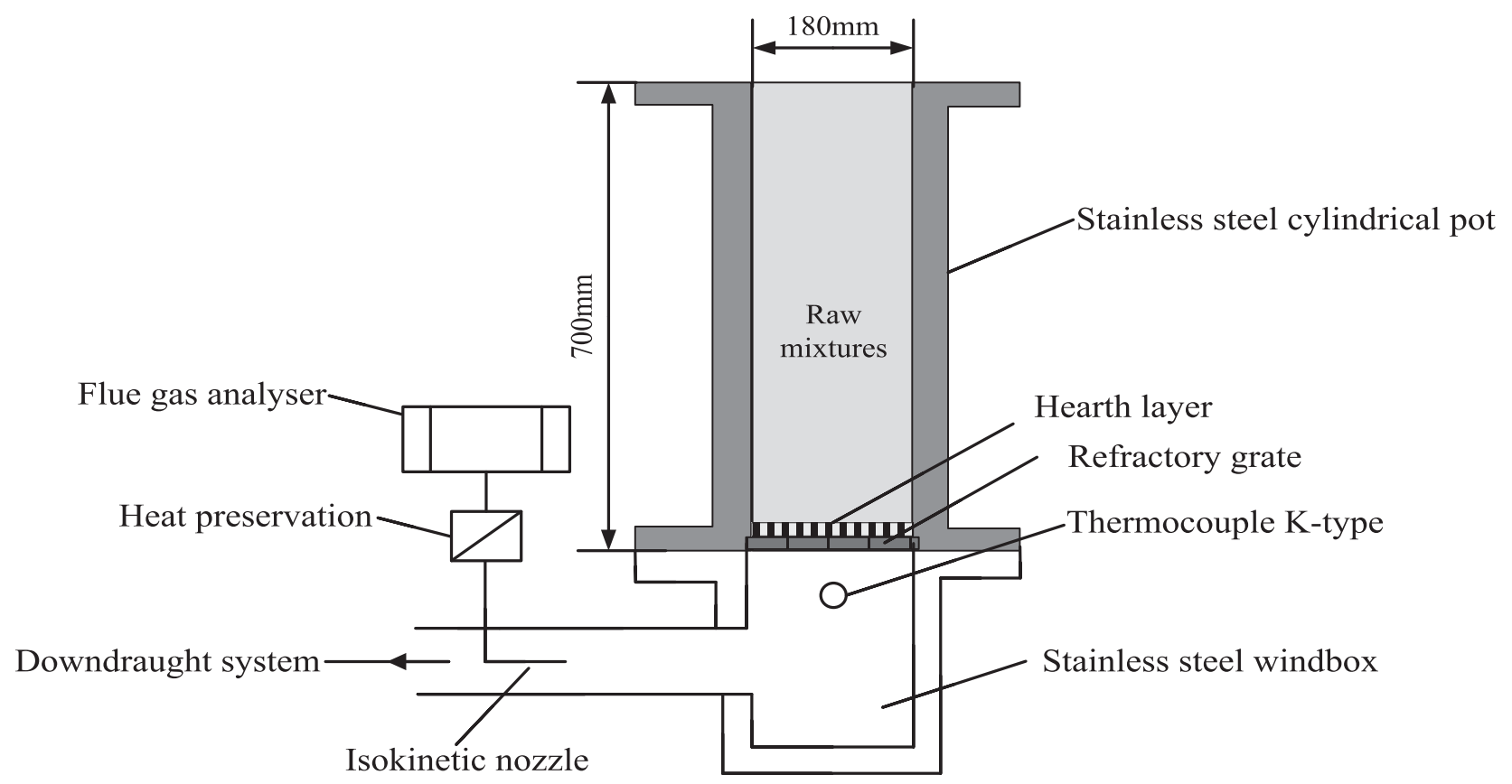

Fig. 2. Schematic diagram of laboratory sinter pot. 
sintering speed, yield, tumble index, productivity. Only when RFB ranged within $1 \pm 0.05$ (mass ratio), the following tests were conducted. Sintering speed was the ratio of layer height and sintering time. Yield was the percentage of sinter above $5 \mathrm{~mm}$ after screening, and the mass of hearth layer was deducted. Productivity reflected the quantity of sinter produced unit area and unit time. Tumble index reflected sinter strength, which was based on the methodology outlined in ISO3271-711.

\section{Results and Discussion}

\subsection{Influences of Preparation Technologies on Basic Physiochemical Properties of Straw Char}

\subsubsection{One-stage Carbonisation}

Results on influences of main factors of one-stage carbonisation on changes in yield, fixed carbon content, volatile content and ash content are described in Table 4 . With carbonisation temperature increasing, where heating rate and carbonisation time were kept at $25^{\circ} \mathrm{C} / \mathrm{min}$ and $30 \mathrm{~min}$, yield and volatile matters tended to decrease, the results were similar to that described by Shigeru. ${ }^{17)}$ Possible reason was the deep removal of $\mathrm{O}$ and $\mathrm{H}$ in raw straw at higher temperature for greater carbonisation intensity. Increased fixed carbon content was then the result that more carbon was entered into solid products at higher carbonisation temperature. When carbonisation temperature was $500^{\circ} \mathrm{C}$, fixed carbon content had reached $75.11 \%$. However, volatile content was much higher than coke breeze, which was reduced to be close to coke breeze after increasing carbonisation

Table 4. Influence of carbonisation factors on proximate analyses (dry basis).

\begin{tabular}{lrrcrc}
\hline Carbonisation factors & & Yield & Fixed carbon & Volatile & Ash \\
\hline & 500 & 31.40 & 75.11 & 11.06 & 13.83 \\
Carbonisation & 600 & 25.50 & 77.01 & 6.84 & 16.15 \\
temperature $\left({ }^{\circ} \mathrm{C}\right)$ & 700 & 24.42 & 77.91 & 4.39 & 17.70 \\
& 800 & 24.02 & 78.01 & 3.71 & 18.28 \\
\hline & 10 & 25.85 & 78.6 & 3.76 & 17.64 \\
Heating & 25 & 24.42 & 77.91 & 4.39 & 17.70 \\
rate $\left({ }^{\circ} \mathrm{C} / \mathrm{min}\right)$ & 100 & 22.28 & 77.16 & 6.26 & 16.58 \\
& 200 & 21.52 & 77.07 & 6.82 & 16.11 \\
\hline & 10 & 25.38 & 76.56 & 7.93 & 15.51 \\
Carbonisation & 20 & 25.15 & 77.44 & 6.15 & 16.41 \\
time (min) & 30 & 24.42 & 77.91 & 4.39 & 17.70 \\
& 60 & 23.59 & 78.22 & 3.83 & 17.95 \\
\hline
\end{tabular}

temperature to $700^{\circ} \mathrm{C}$. As further increased temperature just changed yield, fixed carbon, and volatile matter moderately, $700^{\circ} \mathrm{C}$ was selected as proper carbonisation temperature to prepare straw char.

Keeping carbonisation temperature and carbonisation time at $700^{\circ} \mathrm{C}$ and $30 \mathrm{~min}$, increasing heating rate gave rise to the decrease in yield and fixed carbon content, and was adverse to the removal of volatile matter. Especially when heating rate increased from $10^{\circ} \mathrm{C} / \mathrm{min}$ to $200^{\circ} \mathrm{C} / \mathrm{min}$, yield, fixed carbon content dropped from $25.85 \%, 78.60 \%$ to $21.52 \%, 77.07 \%$, while volatile content increased from $3.76 \%$ to $6.82 \%$. Potential explanation was that raw straw was heated to $700^{\circ} \mathrm{C}$ within a short time under excessively high heating rate, which was detrimental to the sufficient removal of $\mathrm{O}$ and $\mathrm{H}$. Besides, excessively high heating rate would lead to the intense decomposition of organics, and potential carbon or inorganic mineral components were removed with flow gas. When heating rate ranged within $10-25^{\circ} \mathrm{C} / \mathrm{min}$, straw char achieved desired fixed carbon contents and volatile matter to that of coke breeze.

Keeping carbonisation temperature and heating rate at $700^{\circ} \mathrm{C}$ and $25^{\circ} \mathrm{C} / \mathrm{min}$. Both yield and volatile content achieved a decrease with carbonisation time prolonging, while fixed carbon content achieved an increase. Possible explanation of this behavior was described as longer carbonisation time contributed to the further removal of $\mathrm{O}$ and $\mathrm{H}$, and more carbon was left to achieve higher fixed carbon content. When carbonisation time stood at $30 \mathrm{~min}$, contents of volatile matter and fixed carbon for straw char had met that of coke breeze.

\subsubsection{Two-stage Carbonisation}

Single stage carbonisation is generally adopted method during biomass or coal carbonisation process, while twostage or other multistage carbonisation is scarcely used. However, multistage carbonisation influenced characteristics of prepared biochar in terms of yield, reactivity and inner structure. ${ }^{15,16)}$ Influences of carbonisation temperature of stage- 1 on characteristics of prepared straw char are given in Table 5, it was found that two-stage carbonisation tended to produce straw char of greater yield, and even lower volatile and higher fixed carbon than one-stage carbonisation when temperature of stage- 1 exceeded $400^{\circ} \mathrm{C}$. However, when increasing the temperature to $600^{\circ} \mathrm{C}$, both fixed carbon content and volatile content changed moderately. Consequently, we selected $500^{\circ} \mathrm{C}$ as proper temperature for stage-1.

Potential reason for superiority of two-stage carbonisation was as follows: cellulose and lignin in raw straw decomposed with competing reactions of de- $\mathrm{H}_{2} \mathrm{O}$, de- $\mathrm{CO}_{2}$,

Table 5. Influences of carbonisation processes on physicochemical characteristics of straw char.

\begin{tabular}{ccccccc}
\hline $\begin{array}{c}\text { Carbonisation } \\
\text { processes }\end{array}$ & $\begin{array}{c}\text { Temperature } \\
\text { of stage-1 }\left({ }^{\circ} \mathrm{C}\right)\end{array}$ & $\begin{array}{c}\text { Temperature } \\
\text { of stage- }\left({ }^{\circ} \mathrm{C}\right)\end{array}$ & $\begin{array}{c}\text { Yield } \\
(\text { mass } \%)\end{array}$ & $\begin{array}{c}\text { Fixed carbon } \\
(\text { mass\% })\end{array}$ & $\begin{array}{c}\text { Volatile } \\
(\text { mass\% })\end{array}$ & $\begin{array}{c}\text { Ash } \\
(\text { mass\% })\end{array}$ \\
\hline One-stage & 700 & - & 24.42 & 77.91 & 4.39 & 17.70 \\
\hline \multirow{2}{*}{ Two-stage } & 500 & & 26.81 & 76.75 & 6.84 & 16.40 \\
& 600 & 700 & 26.37 & 79.28 & 2.82 & 17.90 \\
& 600 & & 26.01 & 79.38 & 2.41 & 18.21 \\
\hline
\end{tabular}

${ }^{\text {a }}$ heating rate was $25^{\circ} \mathrm{C} / \mathrm{min}$, carbonisation time was $30 \mathrm{~min}$. 
Table 6. Chemical composition of straw char.

\begin{tabular}{lccc}
\hline \multirow{2}{*}{ Carbonisation products } & \multicolumn{3}{c}{ Ultimate analyses (mass\%) } \\
\cline { 2 - 4 } & $\mathrm{C}$ & $\mathrm{H}$ & $\mathrm{O}$ \\
\hline One-stage & 78.30 & 1.45 & 2.25 \\
Stage-1 $\left(500^{\circ} \mathrm{C}\right)$ of two-stage & 77.65 & 3.03 & 4.89 \\
Stage-2 $\left(700^{\circ} \mathrm{C}\right)$ of two-stage & 79.65 & 0.86 & 1.18 \\
\hline
\end{tabular}

Table 7. Removal characteristics of $\mathrm{C}, \mathrm{H}$ and $\mathrm{O}$ during carbonisation.

\begin{tabular}{ccrrrrrr}
\hline \multirow{2}{*}{$\begin{array}{c}\text { Carbonisation } \\
\text { process }\end{array}$} & \multicolumn{3}{c}{$\begin{array}{c}\text { Removal percents } \\
\text { of elements (mass\%) }\end{array}$} & \multicolumn{2}{c}{$\begin{array}{c}\text { Removal molar number } \\
\text { of } 100 \text { g raw straw }\end{array}$} \\
\cline { 2 - 8 } & \multicolumn{1}{c}{$\mathrm{C}$} & $\mathrm{H}$ & $\mathrm{O}$ & $\mathrm{H}_{2} \mathrm{O}$ & $\mathrm{CO}_{2}$ & $\mathrm{CH}_{4}$ \\
\hline One-stage & 57.21 & 93.06 & 98.79 & 0.463 & 1.174 & 0.956 \\
\hline \multirow{2}{*}{ Two-stage } & Stage-1 & 45.16 & 87.50 & 96.07 & 0.800 & 0.965 & 0.715 \\
& Stage-2 & 7.84 & 8.05 & 3.25 & -0.143 & 0.116 & 0.174 \\
& Total & 53.00 & 95.55 & 99.32 & 0.657 & 1.081 & 0.889 \\
\hline
\end{tabular}

and de- $\mathrm{CH}_{4},{ }^{17)}$ the comprehensive effect of which determined the yield, fixed carbon and volatile contents of straw char. Table 6 gives the ultimate analyses of $\mathrm{C}, \mathrm{H}$, and $\mathrm{O}$ in straw char, according to which the removal percents of $\mathrm{C}$, $\mathrm{H}$, and $\mathrm{O}$ were figured out by Eq. (2) described ahead. Based on their removal ratios, the removal molar ratio of $\mathrm{C}, \mathrm{H}$, and $\mathrm{O}$ were easily obtained as $\mathrm{CxHyOz}$, according to which the removal molar number of $\mathrm{H}_{2} \mathrm{O}, \mathrm{CO}_{2}$, and $\mathrm{CH}_{4}$ during carbonisation were figured out by molar balance. Results are shown in Table 7, where can be observed that during twostage carbonisation process, de $-\mathrm{H}_{2} \mathrm{O}$ reaction played a more important role in removing $\mathrm{H}, \mathrm{O}$ than that during one-stage carbonisation since higher removal molar number of $\mathrm{H}_{2} \mathrm{O}$ was achieved in two-stage carbonisation. However, the lower removal molar number of $\mathrm{CO}_{2}, \mathrm{CH}_{4}$ showed that de- $\mathrm{CO}_{2}$, de- $\mathrm{CH}_{4}$ reactions during two-stage carbonisation process were inferiorly developed compared with one-stage carbonisation. Therefore, two-stage carbonisation benefited remaining more $\mathrm{C}$ in solid products. In combination with the removal molar percents of $\mathrm{H}_{2} \mathrm{O}, \mathrm{CO}_{2}$, and $\mathrm{CH}_{4}$ during twostage carbonisation, stage- 1 mainly served as the stage to remove major part of $\mathrm{H}, \mathrm{O}$ through de- $\mathrm{H}_{2} \mathrm{O}$, de- $\mathrm{CO}_{2}$ and de$\mathrm{CH}_{4}$ reactions; stage-2 mainly acted as the stage to deep remove $\mathrm{H}, \mathrm{O}$ by means of de- $\mathrm{CO}_{2}$, de- $\mathrm{CH}_{4}$ reactions. The removal molar number of $\mathrm{H}_{2} \mathrm{O}$ in stage- 2 showed a negative value, the possible reason of which was that the removal of $\mathrm{H}, \mathrm{O}$ was not in the form of de- $\mathrm{CO}_{2}$, de- $\mathrm{CH}_{4}$ rigorously. The comprehensive effect of stage- 1 and stage- 2 made two-stage carbonisation superior to one-stage carbonisation in terms of higher yield and fixed carbon content, and lower volatile matters.

\subsection{Influences of Preparation Technologies on Com- bustibility of Straw Char}

From the results shown in Fig. 3, increasing carbonisation temperature from $500^{\circ} \mathrm{C}$ to $700^{\circ} \mathrm{C}$, carbonisation time from $10 \mathrm{~min}$ to $30 \mathrm{~min}$, or decreasing heating rate from $200^{\circ} \mathrm{C} /$ $\min$ to $25^{\circ} \mathrm{C} / \mathrm{min}$ reduced the difference of fuel conversion rate between straw chars and coke breeze. Particularly when carbonisation temperature, heating rate and carbonisation

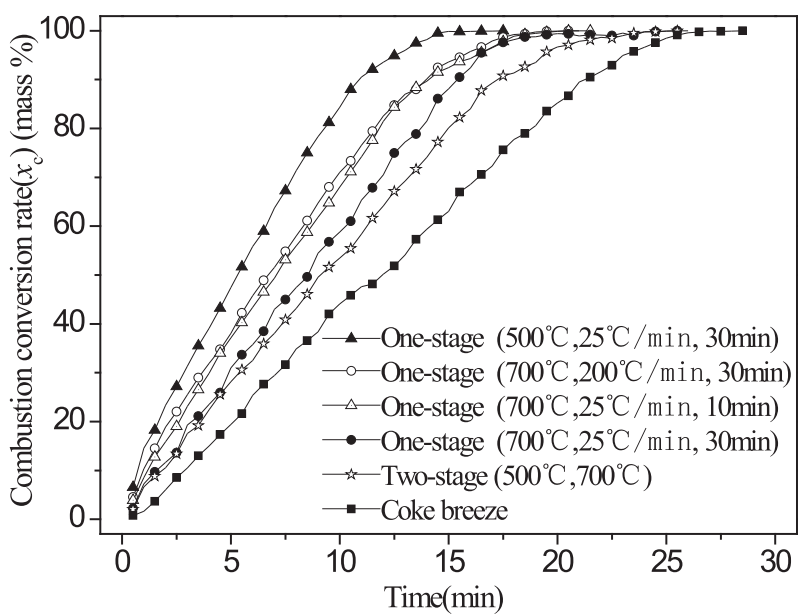

Fig. 3. Influences of carbonisation factors and processes on combustion conversion rates of straw char.

time were in proper values of $700^{\circ} \mathrm{C}, 25^{\circ} \mathrm{C} / \mathrm{min}$ and $30 \mathrm{~min}$, fuel conversion rate differences between two kinds of fuels got further narrowed. Compared with one-stage carbonisation, a closer conversion rate between coke breeze and straw char prepared from two-stage carbonisation was observed.

Different microstructures of straw char (Fig. 4) possibly served as an explanation for changed fuel conversation rates. Compared with straw char prepared under the proper one-stage carbonisation factors (Fig. 4(d)), the inner structure of straw char shown in Fig. 4(a) (carbonisation temperature $500^{\circ} \mathrm{C}$ ), Fig. 4 (b) (heating rate $200^{\circ} \mathrm{C} / \mathrm{min}$ ), and Fig. 4(c) (carbonisation time $10 \mathrm{~min}$ ) was looser, and more pores were observed. Therefore, straw char prepared under these factors had a larger reaction area with air when combusting under high temperature, which made straw char burn up within a shorter period. Structure of straw char prepared in two-stage carbonisation (Fig. 4(e)) achieved further densification compared with that shown in Fig. 4(d). The changed structure coincided with the reduced fuel conversion rate difference shown in Fig. 3. The formation of this structure was related to lower temperature stage-1, which made organics porolyse mildly and less damage to straw inner structure when removing porolysed gas or oil. However, when heating raw straw to $700^{\circ} \mathrm{C}$ without any transition, organics were then directly exposed to high carbonisation intensity. The pressure formed by porolysed gas or oil inside straw would be larger than lower carbonisation temperature, more potential pores in straw char therefore were left. However, further research in terms of the mineral changes in ash should be done to clarify in details the changes of combustibility, since inorganic matter correlated with fuel reactivity. ${ }^{15,18)}$

\subsection{Application of Straw Char in Iron Ore Sintering}

\subsubsection{Influences on Sintering Indices}

For examining the influences of prepared fuels on sintering indices, straw char prepared from proper factors of one-stage carbonisation and two-stage carbonisation were selected. The weight of straw char for each run was calculated on the basis of heat balance, which meant that straw char provided equal amount of heat that the coke breeze replaced released. Prior to sintering trials, straw char was crushed and screened. The 

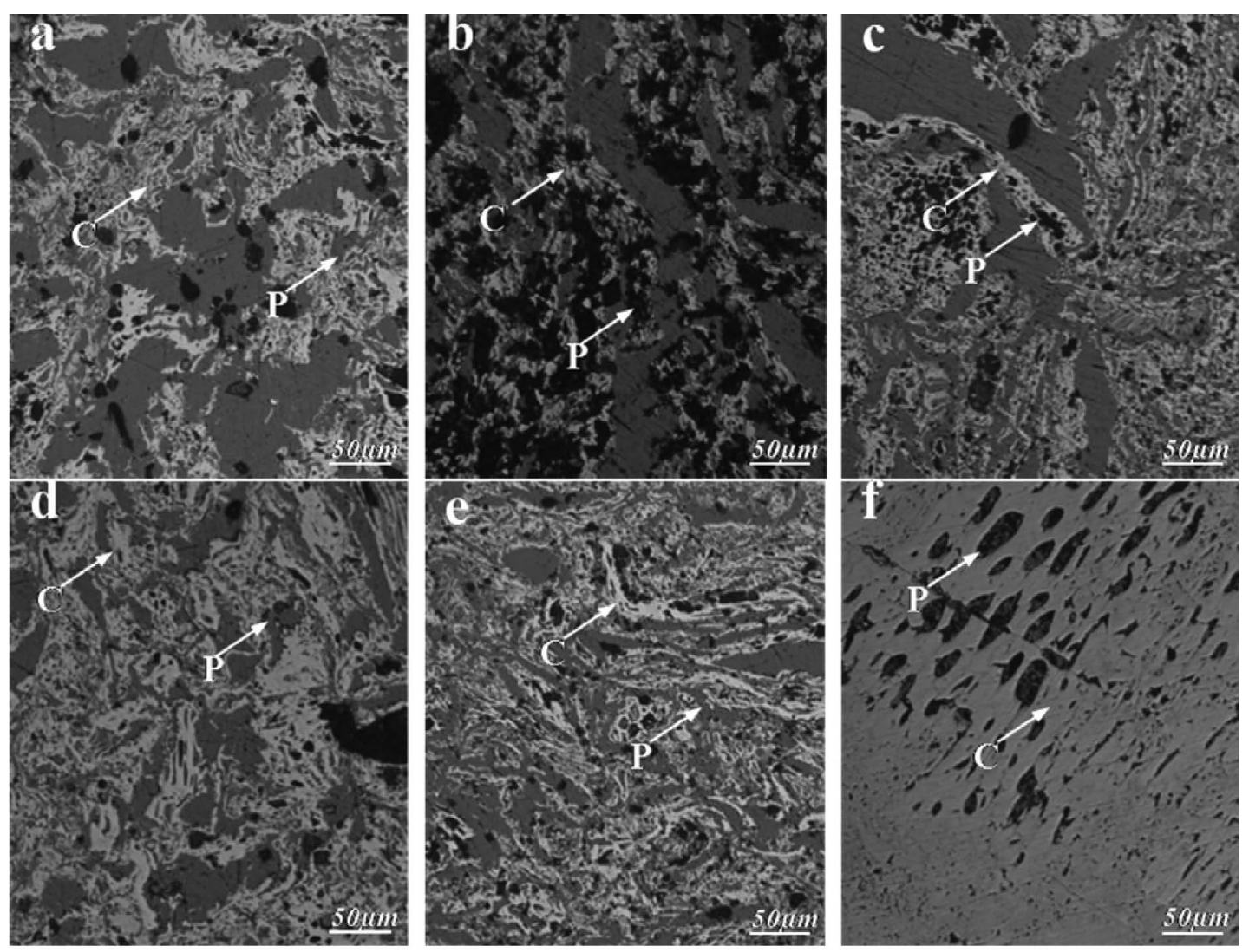

C- carbon; P- pore

Fig. 4. Influences of carbonisation processing on microstructures of straw char. (a) one-stage carbonisation $\left(500^{\circ} \mathrm{C}, 25^{\circ} \mathrm{C} / \mathrm{min}\right.$, $30 \mathrm{~min})$; (b) one-stage carbonisation $\left(700^{\circ} \mathrm{C}, 200^{\circ} \mathrm{C} / \mathrm{min}, 30 \mathrm{~min}\right)$; (c) one-stage carbonisation $\left(700^{\circ} \mathrm{C}, 25^{\circ} \mathrm{C} / \mathrm{min}, 10\right.$ $\mathrm{min})$; (d) one-stage carbonisation $\left(700^{\circ} \mathrm{C}, 25^{\circ} \mathrm{C} / \mathrm{min}, 30 \mathrm{~min}\right)$; (e) two-stage carbonisation $\left(500^{\circ} \mathrm{C}, 700^{\circ} \mathrm{C}\right)$; (f) coke breeze.

Table 8. Influence of carbonisation processes on sintering indexes.

\begin{tabular}{ccccccccc}
\hline Fuel types & $\begin{array}{c}\text { Carbonisation } \\
\text { processes }\end{array}$ & $\begin{array}{c}\text { Replacement ratio } \\
(\mathrm{mass} \%)\end{array}$ & $\begin{array}{c}\text { Sintering speed } \\
\left(\mathrm{mm} \cdot \mathrm{min}^{-1}\right)\end{array}$ & $\begin{array}{c}\text { Yield } \\
(\mathrm{mass} \%)\end{array}$ & $\begin{array}{c}\text { Tumble } \\
\text { Index (mass\%) }\end{array}$ & $\begin{array}{c}\text { Productivity } \\
\left(\mathrm{t} \cdot \mathrm{m}^{-2} \cdot \mathrm{h}^{-1}\right)\end{array}$ & $\begin{array}{c}\text { Reduction of SOx } \\
(\mathrm{mass} \%)\end{array}$ & $\begin{array}{c}\text { Reduction of NOx } \\
(\mathrm{mass} \%)\end{array}$ \\
\hline Coke breeze & - & 0 & 21.94 & 72.66 & 65.00 & 1.48 & - & - \\
\hline \multirow{5}{*}{ Straw char } & One-stage & 20 & 23.05 & 69.78 & 64.62 & 1.47 & 10.98 & 12.67 \\
& One-stage & 40 & 25.12 & 65.53 & 62.25 & 1.40 & - & - \\
& Two-stage & 20 & 22.18 & 71.79 & 64.85 & 1.47 & - & - \\
& Two-stage & 40 & 23.20 & 71.05 & 64.55 & 1.48 & 38.15 & 22.53 \\
& Two-stage & 60 & 25.86 & 64.09 & 60.22 & 1.41 & - & - \\
\hline
\end{tabular}

fraction with the same size range as coke breeze was preferred. Proper moisture content on individual run was determined when sintering indexes were optimal. Table 8 shows the results of sintering trials.

When straw char prepared from one-stage and two-stage carbonisation replaced coke breeze by $20 \%, 20-40 \%$ respectively, sintering indices changed slightly compared with base run where only coke breeze was applied. However, sinter strength degraded remarkably after replacing coke breeze excessively. Potential explanation was that greatly increased sintering speed decreased the top temperature required to form adhesive phase that guaranteed sinter quality as the balance between combustion front and heat transfer front was damaged. ${ }^{11,19)}$ Therefore, recommended ratio for replacing coke breeze for straw char prepared from one-stage carbonisation was $20 \%$, and for two-stage carbon- isation was $40 \%$.

\subsubsection{Influences on Emissions Reduction}

Equation (4) was employed to calculate reduced emission of SOx, NOx, where $R_{S O x / N O x}$ is the reduction ratio of SOx or NOx, $Q_{0}$ is sampled total flue gas flow in base run, $t_{0}$ is the total sintering time in base run, $c_{t}$ is the concentration of SOx or NOx at time $t$ in base run; $Q_{1}$ is sampled total flue gas flow, $t_{1}$ is the total sintering time, and $c_{t}$ is the concentration of SOx or NOx at time $t$ when coke breeze was replaced. The Emission reduction of SOx, NOx in flue gas for each run was described in Table 8 .

$$
R_{\text {SOX } / N O x}=\frac{Q_{0} \int_{0}^{t_{0}} c_{t} d t-Q_{1} \int_{0}^{t_{1}} c_{t 1} d t}{Q_{0} \int_{0}^{t_{0}} c_{t} d t} \cdot 100
$$




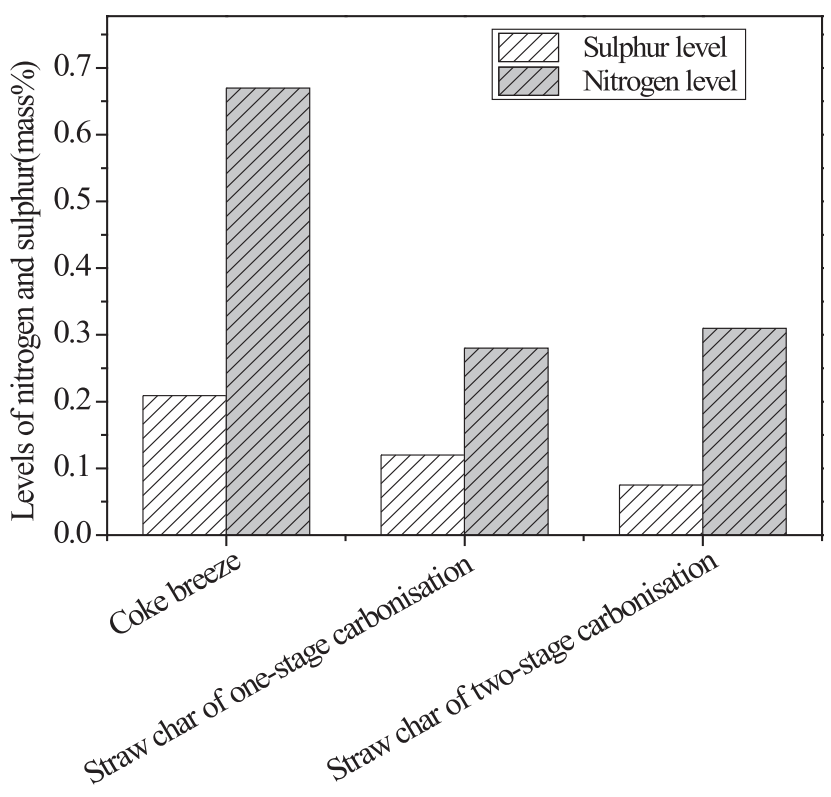

Fig. 5. Nitrogen and sulphur levels in fuels.

As can be clearly observed, the concentrations of SOx, NOx in sintering flue gas was reduced with coke breeze partially replaced. The lower levels of surphur and nitrogen in straw char given in Fig. 5 explained emissions reduction of SOx, NOx since they mainly came from the conversation of sulphur and nitrogen in fuels. When $20 \%$ of coke breeze was replaced by straw char prepared from one-stage carbonisation, emission reduction of SOx, NOx achieved 10.98\%, $12.67 \%$ respectively. As straw char prepared from two-stage carbonisation could replace coke breeze by $40 \%$, emissions of SOx, NOx were accordingly reduced by $38.15 \%, 22.53 \%$ respectively.

\section{Conclusions}

An investigation was carried out regarding preparation technologies of corn straw char and its application as an alternative fuel for iron ore sintering. It concluded:

(1) In this investigation, recommended conditions for one-stage carbonisation include carbonisation temperature of $700^{\circ} \mathrm{C}$, heating rate of $10-25^{\circ} \mathrm{C} / \mathrm{min}$, and carbonisation time of $30 \mathrm{~min}$. Two-stage carbonisation facilitates the further removal of volatile matters, and making straw char increased in yield and fixed carbon content, where recommended carbonisation temperature for stage- 1 is $500^{\circ} \mathrm{C}$ when stage- 2 is $700^{\circ} \mathrm{C}$. Straw char yielded under recommended conditions has similar volatile and fixed carbon contents to coke breeze.

(2) Straw char prepared from the recommended conditions shows close combustibility to coke breeze as densified strucuture is achieved. Compared with one-stage carbonisation, two-stage carbonisation makes straw char more densified in structure and less difference in combustibility to coke breeze.

(3) Straw char prepared from recommended one-stage carbonisation and two-stage carbonisation is able to replace coke breeze by $20 \%, 40 \%$ respectively, where emission reduction for SOx is reduced by $10.98 \%, 38.15 \%$ respectively, and for NOx is reduced by $12.67 \%, 22.53 \%$ respectively.

\section{Acknowledgements}

The authors are grateful to programs supported by National Natural Science Fund (No.51174253, No.51304245), and also to the support of Chinese Postdoctoral Science Foundation (2013M540639).

\section{REFERENCES}

1) L. Xu: Natl. Conf. Proc. on Raw Iron, The Chinese Society for Metals, Beijing, (2005), 25 (in Chinese).

2) Y. G. Chen, Z. C. Guo and Z. Wang: Fuel Proc. Tech., 90 (2009), 933.

3) T. C. Ooi, D. Thompson, D. R. Anderson, R. Fisher, T. Fray and M. Zandi: Comb. Flame, 158 (2011), 979.

4) R. Lovel, K. Vining and M. Dell'Amico: Min. Proc. Extr. Met., 116 (2007), 85.

5) R. Lovel, K. Vining and M. Dell'Amico: ISIJ Int., 49 (2009), 195.

6) L. M. Lu, M. Adam, M. Kilburn, S. Hapugoda, M. Somerville, S. Jahanshahi and J. G. Mathieson: ISIJ Int., 53 (2013), 1607.

7) T. C. Ooi, E. Aries, B. C. R. Ewan, D. Thompson, D. R. Anderson, R. Fisher, T. Fray and D. Tognarelli: Miner. Eng., 21 (2008), 167.

8) M. Zandi, M. M. Pacheco and T. A. T. Fray: Miner. Eng., 23 (2010), 1139.

9) M. Gan, X. H. Fan, X. L. Chen, Z. Y. Ji, W. Lv, Y. Wang, Z. Y. Yu and T. Jiang: ISIJ Int., 52 (2012), 1580.

10) M. Gan, X. H. Fan, Z. Y. Ji, X. L. Chen, T. Jiang and Z. Y. Yu: Ironmaking Steelmaking, 41 (2014), 430.

11) J. Y. Fu, T. Jiang and D. Q. Zhu: Pelletising \& Sintering. Central South University Press, Changsha, (1996), (in Chinese).

12) L. Shi, Y. C. Zhao and X. L. Chai: China Biogas, 23 (2005), 11 (in Chinese).

13) R. Lal and D. Pimentel: Soil Till. Res., 93 (2007), 237.

14) R. C. Guo, J. R. Tang, H. Xu and H. C. Ma: J. For. Inv. Planning, 32 (2007), 90 (in Chinese)

15) E. Iniesta, F. Sanchez, A. N. Garcia and A. Marcila: J. Anal. Appl. Pyrolysis, 59 (2001), 983.

16) E. Iniesta, F. Sanchez, A. N. Garcia and A. Marcila: J. Anal. Appl. Pyrolysis, 59 (2001), 967.

17) S. G. Ueda, K. Watanabe, K. Yanagiya, R. Inoue and T. Ariyama: ISIJ Int., 49 (2009), 1505.

18) D. S. Chang: Fuel, 86 (2007), 2316.

19) C. E. Loo: Min. Proc. Extr. Met., 109 (2000), 11. 